Darius von Güttner Sporzyński - 'Recent Issues in Polish Historiography of the Crusades.' Presented at the Fourth International Conference of the London Centre for the Study of the Crusades, the Military Religious Orders and the Latin East, St John's Gate, London, 8-11 September 2005.

\title{
Recent Issues in Polish Historiography of the Crusades.
}

\section{Introduction}

Writing in the 1880s, Stanisław Smolka observed that 'the Poles were not too eager to venture on the crusades. ${ }^{1}$ Generations of historians since then have accepted this view and over time a tendency has developed among Polish historians to marginalize the impact of the idea of crusade in Poland and to devalue the participation of Poles in the crusades as politically motivated episodes of early Polish imperialism. This situation has no doubt been exacerbated by the limited amount of primary material on the subject of the crusades - which allowed for wide interpretational differences, by the political climate after 1945, and by post-war anti German sentiment, which influenced attitudes towards the Teutonic Order and its place in Polish history. ${ }^{2}$

In this paper I will present an overview of some recent issues to have emerged from the Polish historiography of the crusades. I will concentrate on the most prominent works which dealt with the crusades, crusading and the military religious orders. However, due to the space limitations of this paper, I will not give a consideration of the historiography of the Teutonic Order, which due to its enormous size, deserves to be treated separately.

Polish historiography of the crusades presents challenges, as much from the medieval period it considers, as from the eras in which its historians have lived; this is particularly true of the historiography of the twentieth century. Crusading was not a popular movement in medieval Poland transcending the 'class divide,' and its followers were recruited from the ruling dynasty and the knighthood - a set of circumstances at odds with the ideological dogma of post-war Poland. An orthodoxy developed which held that the Poles were disinterested in crusading. ${ }^{3}$ Such a stand

\footnotetext{
${ }^{1}$ Stanisław Smolka, Mieszko Stary i jego wiek, ed. Aleksander Gieysztor (Warszawa: Gebethner i Wolff, 1881; reprint, Warszawa: Państwowe Wydawnictwo Naukowe, 1959), 65.

${ }^{2}$ The approach taken in older research was to examine Polish contacts with the Holy Land. See Mathias Bersohn, Kilka stów o polskich podróżnikach do Ziemi Świętej i ich dziełach, Biblioteka Warszawska, 4 (Warsaw: 1868); Jan Stanisław Bystroń, Polacy w Ziemi Świętej, Syrji i Egipcie 1747-1914 (Kraków: 1930); Stanisław A. KorwinPawłowski, Stosunki Polski z Ziemiq Święta (Warszawa: Instytut Wydawniczy PAX, 1958).

${ }^{3}$ Benedykt Zientara observed that 'very quickly Poland used the idea of crusade in the wars with their pagan neighbours,' but he concluded that 'by and large, the idea of fighting in the defence of Christendom.... in the Middle Ages had not gained mass support in Poland.' Benedykt Zientara, "Afterword to "Dzieje wypraw krzyżowych"," in Polish edition of A History of Crusades by Steven Runciman (Warszawa: Państwowy Instytut Wydawniczy, 1987), 459.
} 
Darius von Güttner Sporzyński - 'Recent Issues in Polish Historiography of the Crusades.' Presented at the Fourth International Conference of the London Centre for the Study of the Crusades, the Military Religious Orders and the Latin East, St John's Gate, London, 8-11 September 2005.

was adopted, not simply because crusading was seen as an expression of religious fanaticism and the domain of the aristocracy, but mainly because according to popular opinion, crusading was associated with the activities of the Teutonic Order, which after 1945 became a synonym for German militarism and the Drang Nach Osten.

In the last decade the Polish historiographical position has begun shifting, the result of the publication of research by a new generation of historians, most notably Mikołaj Gładysz, Maria Starnawska, and Janusz Trupinda. Now, far from claiming the Poles displayed an aversion to crusading, the new scholars are demonstrating that Poles were among the first and enthusiastic participants in the crusades.

\section{Discussion}

There are few Polish medieval narrative sources which offer information about Polish involvement in crusading. Among them is the oldest extant narrative source from and about Poland, the Gesta Principum Polonorum (recently available in a parallel Latin English edition). ${ }^{4}$ The Gesta, written about twenty years after the First Crusade, is the oldest source to relate the sequence of events of early Polish history, and culminates with the reign of Bolesław III (the Wrymouth) (1102-1138). Its third book in particular reflects the crusading ideology of Bolesław's court, as it dwells on Bolesław's campaigns against the Pomeranians and Prussians. ${ }^{5}$

The Chronicon Polonorum by Master Wincenty Kadłubek (ca. 1150-1223) has a different character to the Gesta, and notably less emphasis on crusading ideology. However, the Polish expeditions by Bolesław the Wrymouth in 1109 against the Pomeranians, Bolesław IV (the Curly) to Prussia in 1147 and 1166, and Casimir I (the Just) in 1191-1192 against the Sudovians, are all portrayed as crusading engagements. ${ }^{6}$ Master Wincenty describes the Prussians as 'Saladinistas' and clearly

\footnotetext{
${ }^{4}$ Paul W. Knoll and Frank Schaer, eds., Gesta Principium Polonorum: the Deeds of the Princes of the Poles, Central European Medieval Texts, vol 3 (Budapest-New York: Central European University Press, 2003).

${ }^{5}$ Andrzej F. Grabski, "Polska wobec idei wypraw krzyżowych na przełomie XI i XII wieku: duch krzyżowy Anonima Galla," Zapiski Historyczne 26 (1961): 62-63.

${ }^{6}$ Marian Plezia, ed., Magistri Vincentii dicti Kadtubek Chronica Polonorum, Monumenta Poloniae Historica n.s. (Kraków: Polska Akademia Umiejętności, 1994), 4, 19.14, 166. Cf. Mikołaj Gładysz, Zapomniani krzyżowcy (Warszawa: DiG, 2002), 36-37; Roman Grodecki, "Polska wobec idei wypraw krzyżowych," Przeglad Wspótczesny 2, no. 18 (1923): 111.
} 
Darius von Güttner Sporzyński - 'Recent Issues in Polish Historiography of the Crusades.' Presented at the Fourth International Conference of the London Centre for the Study of the Crusades, the Military Religious Orders and the Latin East, St John's Gate, London, 8-11 September 2005.

favours the use of force against the Prussian apostates to compel them to accept Christianity.

The monumental Annales seu cronici incliti regni Poloniae of Jan Długosz (14151480) provide a fifteenth-century perspective on the events of Polish history and the experience of crusading in Poland. Among numerous examples of the manifestations of crusading in Poland, Długosz relates the crusading of Henry of Sandomierz to the Holy Land and his death in the expedition against the Prussians in 1166. Curiously, Długosz speaks about the otherwise unknown plans of Bernard of Clairvaux to travel to Poland to preach the Second Crusade and organize a Catholic mission to Orthodox Ruthenia. ${ }^{7}$ Długosz however, is not consistent in his treatment of the military religious orders, and often mistakes Hospitallers for Templars, and prefers to denominate them using the generic term of 'crucifieri.'

The Polish historiographical discourse on crusades does not lack contentious statements. Stanisław Zakrzewski observed that Poland 'got away with abstaining from the Levantine crusades because the Poles invented their own Saracens in the neighbouring Wends and Prussians. ${ }^{8}$ This statement was criticised by Roman Grodecki who surveyed the involvement of Poles in crusading and argued that their participation was the result of general European crusading efforts. Grodecki however also maintained that crusading ideology was forced upon Poles as if by "peer pressure' from other Christian nations. ${ }^{9}$ Grodecki idealised the motives of the Poles, and emphasized that the Poles did not adopt crusading as a pretext for their military and expansionist campaigns against the Prussians because, he argued, the Polish knighthood possessed 'an aversion to the use of force in the matters of faith., ${ }^{10}$ Notwithstanding this aversion, he noted that the Poles waged war when the politics of state demanded it, and observed that the Polish expeditions to Pomerania were always

\footnotetext{
${ }^{7}$ According to Długosz, Bernard of Clairvaux was to visit the Abbey in Jędrzejów after preaching in Speyer in December 1146 and January 1147. Jan Długosz, Joannis Dlugossii Annales seu Cronicae incliti Regni Poloniae. Lib. 5-6, ed. Krystyna Pieradzka, Zofia Kozłowska-Budkowa, and Danuta Turkowska (Varsaviae: Państwowe Wydawnictwo Naukowe, 1973), 12-13.

${ }^{8}$ Stanisław Zakrzewski, "Wschód i Zachód w historii Polski," in Zagadnienia historyczne, ed. Stanisław Zakrzewski (Lwów: Księgarnia H. Altenberga, 1908), 137.

${ }^{9}$ Grodecki, "Polska wobec idei," 103-116.

${ }^{10}$ The example often used is the Polish position at the Council of Constance when the Polish delegation rejected the forceful conversion of pagans and supported pagan rights to self-determination. Stanislaus F. Belch, Paulus Vladimiri and His Doctrine Concerning International Law and Politics, 2 vols. (The Hague: Mouton, 1965).
} 
Darius von Güttner Sporzyński - 'Recent Issues in Polish Historiography of the Crusades.' Presented at the Fourth International Conference of the London Centre for the Study of the Crusades, the Military Religious Orders and the Latin East, St John's Gate, London, 8-11 September 2005.

seen by the Poles as crusades. ${ }^{11}$ Grodecki's argument that the idea of crusade was forced upon the Poles is highly debatable. Nonetheless his article became a starting point for later historians who followed in the examination of the influence of the idea of crusade on Poland, and the Poles' involvement in crusading.

A contemporary of Grodecki, Andrzej Grabski, examined the presence of crusading ideology in the Gesta Principum Polonorum. ${ }^{12}$ In his detailed examination of the concept of the idea of crusade, Grabski followed the ideas of Erdmann, ${ }^{13}$ Rousset, ${ }^{14}$ and Villey, ${ }^{15}$ and concluded that the Gesta not only reflected crusading ideology, but also revealed the attitude of the court of Bolesław the Wrymouth to crusading. Thus the magnates and the prelates, as the ruling elites of Poland, adapted for their own purposes the idea of crusade as manifested through the expeditions against the Prussians, Sudovians and Pomeranians. Grabski, and also subsequently Benedykt Zientara and Maria Starnawska, observed that the concept of crusading was not commonly known to Polish society.

In the tradition of Grabski's study, Janusz Trupinda presented a comprehensive analysis of the idea of crusade in the Chronicle of Peter of Dusburg. The Chronicle is an important source to the history of the Teutonic Order and the culture of crusading in Prussia, and received the attention of a number of prominent Polish historians. ${ }^{16}$

\footnotetext{
${ }^{11}$ Grodecki, "Polska wobec idei," 107-108.

${ }^{12}$ Grabski, "Polska wobec idei," 37-63.

${ }^{13}$ Carl Erdmann, Die Entstehung des Kreuzzugsgedankens (Stuttgart: 1935).

${ }^{14}$ Paul Rousset, Les origines et les caractères de la première croisade (Genáeve: Imprimerie A. Kundig, 1945; reprint, 1978).

${ }^{15}$ Michel Villey, La croisade: Essai sur la formation d'une théorie juridique (Paris: 1942; reprint, 1980).

${ }^{16}$ For example Marian Biskup, Tomasz Jasiński, Karol Górski, Gerard Labuda, Marzena Pollakówna, Jan Powierski and Jarosław Wenta. Marian Biskup and Gerard Labuda, Dzieje zakonu krzyżackiego w Prusach (Gdańsk: 1988); Tomasz Jasiński, Najstarsze kroniki i roczniki krzyżackie dotyczqce Prus, vol. 52, Prace Komisji Historycznej (Poznań: Poznańskie Towarzystwo Przyjaciół Nauk, 1956); Gerard Labuda, "O źródłach "Kroniki Pruskiej” Piotra z Dusburga," Komunikaty Mazursko-Warmińskie, no. 2-3 (1971): 217-243; Marzena Pollakówna, Kronika Piotra z Dusburga (Wrocław: 1968); Jan Powierski, Stosunki polsko-pruskie do 1230 roku ze szczególnym uwzględnieniem roli Pomorza Gdańskiego, Roczniki Towarzystwa Naukowego w Toruniu (Poznań: Państwowe Wydawnictwo Naukowe, 1968); Jan Powierski, "Polska a Prusy do połowy XIII wieku," in Dzieje Warmi i Mazur w zarysie (Warszawa: 1981); Jan Powierski, Prusowie, Mazowsze i sprowadzenie Krzyżaków do Polski (Malbork: Muzeum Zamkowe, 1996); Jan Powierski, Prussica : artykuly wybrane z lat 1965-1995 (Malbork: Muzeum Zamkowe, 2004); Jarosław Wenta, "Kronika Piotra z Duisburga a dzieje Zakonu Krzyżackiego zawarte w Kronice oliwskiej," Studia Źródloznawcze 25 (1970): 121-131; Jarosław Wenta, Kierunki rozwoju rocznikarstwa w państwie Zakonu Niemieckiego w XIII-XVI wieku, Roczniki Towarzystwa Naukowego w Toruniu (Toruń Towarzystwo Naukowe w Toruniu, 1990); Jarosław Wenta, Kronika Piotra z Dusburga: szkic źródloznawczy (Toruń: Wydawnictwo Uniwersytetu Mikołaja Kopernika, 2003); Jarosław Wenta, ed., Kronika ziemi pruskiej Piotra z Dusburga (Torun: Wydawnictwo Uniwersytetu Mikołaja Kopernika, 2004).
} 
Darius von Güttner Sporzyński - 'Recent Issues in Polish Historiography of the Crusades.' Presented at the Fourth International Conference of the London Centre for the Study of the Crusades, the Military Religious Orders and the Latin East, St John's Gate, London, 8-11 September 2005.

Trupinda based his study upon a comprehensive outline of the evolution of the idea of crusade. Trupinda argued that the Chronicle was written by an apologist for the Teutonic Order to inspire, support, and promote the idea of crusade and spiritual renewal of the Order, modelled on the spirit of knightly religiosity promoted by Bernard of Clairvaux. ${ }^{17}$

The identification of individual crusade participants is seen as an important part of the studies of the crusades. ${ }^{18}$ In the 1920s, Michał Mendys investigated and explored issues relating to the identity of anonymous Polish princes who took the Cross during the Second and Fifth Crusades. ${ }^{19}$ Mendys used a reference to the 'King of the Poles' by a Greek Chronicler John Kinnamos, to postulate that Władysław II (the Exile), the deposed Grand Duke of Poland, took a large contingent of Polish troops with the German and Czech forces on the Second Crusade. ${ }^{20}$ An alternative hypothesis identifying Henry of Sandomierz with the 'King of the Poles' which I find credible, has been proposed recently by Mikołaj Gładysz. ${ }^{21}$

\footnotetext{
${ }^{17}$ Janusz Trupinda, Ideologia krucjatowa w Kronice Piotra z Durburga (Gdańsk: Officina Ferberiana, 1999).

${ }^{18}$ Jonathan Riley-Smith, "Family Traditions and Participation in the Second Crusade," in The Second Crusade and the Cistercians, ed. Michael Gervers (New York: St. Martin's Press, 1992), 101-108.

${ }^{19}$ Michał Mendys, "Udział Władysława II w krucjacie 1147," Rocznik Zakładu Naukowego im. Ossolińskich 1 (1927): 399-434. Also Bronisław Włodarski examined a Hungarian charter (dated 1246) which refers to an unnamed Duke of Poland who accompanied King Andrew II of Hungary on crusade in 1217. Włodarski examined the evidence for and against a number of potential candidates, and in conclusion strongly supported Władysław Odonic, Duke of Great Poland, as the most plausible candidate. His source is a note in a Hungarian charter dated 1246 which refers to an unnamed Duke of Poland. Włodarski examined the evidence for and against all the potential candidates, and in conclusion strongly supported Władysław Odonic as the most plausible candidate. See Bronisław Włodarski, "O udziale Polski w wyprawie krzyżowej Andrzeja II w 1217 roku," Kwartalnik Historyczny 38, no. 1-2 (1924): passim.

${ }^{20}$ Mendys argued that after the futile expedition of Conrad III in Poland in 1146, Władysław II had to concentrate on diplomatic manoeuvring to regain the Polish throne and forego all other avenues, including military takeover. Taking of the cross by the excommunicate was, according to Mendys, designed to win the support of the Pope and in turn the favour of the Polish episcopate, which was of utmost importance as the prelates were opposed to the Exile's return to the throne of Cracow. See John Kinnamos, Deeds of John and Manuel Comnenus, trans. Charles M. Brand (New York: Columbia University Press, 1976), 70; Mendys, "Udział Władysława II w krucjacie 1147," 407-410. Kinnamos as a chronicler and historian is discussed also by Wojciech Iwańczak, "Udział Czechów w krucjatach do Ziemi Świętej," in Peregrinationes: Pielgrzymki w kulturze dawnej Europy, ed. Halina Manikowska and Hanna Zaremska, Colloquia Mediaevalia Varsoviensia 2 (Warszawa: Instytut Historii PAN, 1995), 120-121; Jadwiga Ossowska, "The Polish Contribution to the Expeditions to the Holy Land in the Crusades' era," Folia Orientalia 26 (1989): 169; Georgije Ostrogorski, Dzieje Bizancjum, trans. Halina Evert-Kappesowa (Warszawa: Państwowe Wydawnictwo Naukowe, 1967), 288.

${ }^{21}$ Mikołaj Gładysz, "W sprawie udziału polskiego księcia w II krucjacie jerozolimskiej (1147-1149)," in Krzyżowcy, kronikarze, dyplomaci, ed. Błażej Śliwiński, Gdańskie Studia z Dziejów Średniowiecza, 4 (GdańskKoszalin: 1997), 33-52; Mikołaj Gładysz, "Udział Polski w V krucjacie lewantyńskiej (1217-1221)," in Szlachta, starostowie, zaciężni, ed. Błażej Śliwiński, Gdańskie Studia z Dziejów Średniowiecza, 5 (Koszalin: Wydawnictwo Miscellanea, 1998), 63-82; Mikołaj Gładysz, "O zapomnianych polskich krzyżowcach: kilka uwag na marginesie wypraw jerozolimskich księcia Henryka Sandomierskiego i Jaksy z Miechowa," in Ksiażęta, urzędnicy, złoczyńcy, ed. Błażej Śliwiński, Gdańskie Studia z Dziejów Średniowiecza, 6 (Gdańsk: Officina Ferberiana, 1999), 45-64; Gładysz, Zapomniani krzyżowcy.
} 
Among historians who had a profound impact on the study of Polish history is Aleksander Gieysztor. In his early research, Gieysztor identified the encyclical of Pope Sergius IV as a forgery produced about the time of the Council of Clermont. Gieysztor suggested that the apparent encyclical's existence may be evidence of the intentions of the animators of the crusading movement who produced the document for use as a propagandist's tool. ${ }^{22}$ Gerard Labuda, in one of his studies, concentrated on the Magdeburg Appeal of 1108 and argued that its existence provides evidence that the idea of crusade reached north central Europe within a decade of the First Crusade and the fall of Jerusalem, and is also an example of an adaptation of the idea of crusade to suit a local environment far away from the Levant. ${ }^{23}$

The Wendish Crusade of 1147 received a lot of attention from Polish historians because of the account in the Annales Magdeburgenses confirming the participation of Polish armies in the Wendish Crusade and the Polish expedition against the Prussians. ${ }^{24}$ According to Smolka, the Polish knighthood took part in the Wendish Crusade on a wave of general enthusiasm for crusading in the wake of the Second Crusade. ${ }^{25}$ He suggested that the motives of the Piasts were largely diplomatic, prompted by a desire for good relations with Saxony. ${ }^{26}$ Another theory was proposed by Zakrzewski, who argued that by being involved in the Wendish Crusade the Piasts wanted to prevent any possible secession of Pomerania-Szczecin from their

\footnotetext{
${ }^{22}$ Aleksander Gieysztor, Ze studiów nad genezq wypraw krzyżowych: encyklika Sergiusza IV (1009-1012) (Warszawa: Towarzystwo Naukowe Warszawskie, 1948).

23 Gerard Labuda, "Wezwanie wschodnioniemieckich feudałów do walki ze Słowianami roku 1108," in Fragmenty dziejów Słowiańszczyznv Zachodniej, ed. Gerard Labuda (Poznań: Poznańskie Towarzystwo Przyjaciół Nauk, 1975), passim.

${ }^{24}$ The Annals do not identify the Polish duke. 'Iter frater ducis Poloniae cum viginti milibus armatorum exiverat. Cuius etiam frater maior cum infinito exercitu adversus Pruscos crudelissimos barbaros venit, et diutius ibi moratus est. Contra quos etiam Rutheni, licet minus catholici tamen christiani nominis karacterem habentes, inestimabili Dei nutu cum maximis armatorum copiis exiverunt.' Annales Magdeburgenses, ed. George H. Pertz, vol. 16, Monumenta Germaniae Historica Scriptores (Hannoverae 1861), 188.

${ }^{25}$ Smolka, Mieszko Stary i jego wiek, 253. A similar position was expressed in Wilhelm Bernhardi, Konrad III, 2 vols., Jahrbücher Deutschen Geschichte (Leipzig: Duncker and Humblot, 1883), 563-564.

${ }^{26}$ Bogusławski accepted this thesis, commenting that the Piasts became a tool in the hands of the Saxon lords. Wilhelm Józef Bogusławski, Dzieje Słowiańszczyzny pótnocno-zachodniej do połowy XIII wieku, 3 vols., vol. 3 (Poznań: 1892), 572. Also Grodecki accepted that the political support of the Saxon margraves for the Piasts was crucial to them at this time: Roman Grodecki, "Dzieje Polski do roku 1194," in Dzieje Polski Średniowiecznej [A History of Medieval Poland], ed. Roman Grodecki, Stanisław Zachorowski, and Jan Dąbrowski (Kraków: Wydawnictwo Platan, 1995), 168-170. Labuda also accepted Smolka's thesis: Gerard Labuda, "Rola Wielkopolski w utrwaleniu rozdrobnienia feudalnego w Polsce," in Dzieje Wielkopolski, ed. Jerzy Topolski (Poznań: 1969), 285.
} 
Darius von Güttner Sporzyński - 'Recent Issues in Polish Historiography of the Crusades.' Presented at the Fourth International Conference of the London Centre for the Study of the Crusades, the Military Religious Orders and the Latin East, St John's Gate, London, 8-11 September 2005.

suzerainty. ${ }^{27}$ Similarly, Gumowski argued that Polish involvement in the expedition against the Wends was a calculated demonstration of power aimed at securing Polish rights to Branibor. ${ }^{28}$ On the other hand Myśliński proposed that the Poles were participating in the Wendish Crusade apparently only to support their Slav neighbours. ${ }^{29}$ The focus of Myśliński’s study centred on political aspects and diplomatic manoeuvring. ${ }^{30}$

Western scholars usually ignore the simultaneous participation by Poles in the Wendish Crusade and in an expedition against the Prussians. In Polish historiography however, there is little disagreement that the Polish contingent at the Wendish Crusade was led by Mieszko III (the Old), Duke of Great Poland, and the army which went against the Prussians was commanded by Bolesław the Curly, the Grand Duke. In his description of the Prussian expedition, Smolka went as far as calling it 'the truly Polish crusade. ${ }^{31}$

A growing number of Central European historians interested in crusading is evident from the papers published following the conference 'The Knighthood of Central and

\footnotetext{
${ }^{27}$ Stanisław Zakrzewski, "Okres do schyłku XII wieku," in Encyklopedia polska vol. 5, p. 1, Historya polityczna Polski, p. 1: Wieki średnie, ed. Stanisław Zakrzewski (Kraków: Polska Akademia Umiejętności, 1920), 109-110. This theory has been accepted in: Jerzy Dowiat, "Ekspansja Pomorza Zachodniego na ziemie wielecko-obodrzyckie w drugiej połowie XII wieku," Przeglad Historyczny 50, no. 4 (1959): 702-703; Mariusz Dworsatschek, Władysław II Wygnaniec (Wrocław: Towarzystwo Przyjaciół Ossolineum, 1998), 130; Benedykt Zientara, "Stosunki polityczne Pomorza Zachodniego z Polską w drugiej połowie XII wieku," Przeglqd Historyczny 61, no. 4 (1970): 549, n. 516.

${ }^{28}$ Marian Gumowski, "Sprawa braniborska XII wieku," Slavia Occidentalis 7 (1928): 128-129.

${ }^{29}$ Kazimierz Myśliński, Bogusław I ksiaże Pomorza Zachodniego, Wydawnictwa Instytutu Bałtyckiego. Prace Badawczo-Naukowe. Seria: Rozprawy (Bydgoszcz: Instytut Bałtycki, 1948), 13; Kazimierz Myśliński, "Polska a Pomorze Zachodnie po śmierci Krzywoustego," Roczniki Historyczne 17 (1948): 42-46; Kazimierz Myśliński, "Sprawa udziału Polski w niemieckiej wyprawie na Słowian Połabskich," in Ars Historica. Prace z dziejów powszechnych i Polski, Seria Historia, nr 71 (Poznań: Uniwersytet im. Adama Mickiewicza, 1976), 357-376; Kazimierz Myśliński, "Księstwo Saskie a Polska w XII wieku," in Niemcy - Polska w Średniowieczu. Materiały z konferencji naukowej zorganizowanej przez Instytut Historii UAMw dniach 14-16 XI 1983 roku, ed. Jerzy Strzelczyk, Seria Historia, Nr 126 (Poznań: 1986), 177; Kazimierz Myśliński, Polska wobec Stowian połabskich do końca wieku XII (Lublin: Wydawnictwo UMCS, 1993), 173-176.

${ }^{30}$ For Mitkowski it was the importance of securing Polish interests in the region. Józef Mitkowski, Pomorze Zachodnie w stosunku do Polski, ed. Prace Instytutu Zachodniego (Poznań: Wydawnictwo Instytutu Zachodniego, 1946), 60-61. Other authors who reached similar conclusions: Tadeusz Silnicki, "Początki chrześcijaństwa i organizacji kościelnej na Pomorzu," in Z dziejów kościola w Polsce: studia i szkice historyczne, ed. Tadeusz Silnicki (Warszawa: Wydawnictwo Pax, 1960), 146-147; Kazimierz Ślaski, "Pomorze Zachodnie w dobie rozwijającego się feudalizmu (1124-1464)," in Historia Pomorza, ed. Gerard Labuda, Kazimierz Ślaski, and Benedykt Zientara (Poznań: Wydawnictwo Poznańskie, 1969), 62, 65; Józef Spors, Studia nad wczesnośredniowiecznymi dziejami Pomorza Zachodniego: XII - pierwsza połowa XIII wieku (Słupsk: Pobrzeże, 1988), 238.

${ }^{31}$ Smolka used terms ,prawdziwie polska krucjata' and suggested that among the reasons for it was „,zapał do walki z poganami, jaki wówczas Polskę ogarnạł' Smolka, Mieszko Stary i jego wiek, 255. Cf. Gładysz, Zapomniani krzyżowcy, 95. Riley-Smith does not identify 'a brother of the duke of Poland' Jonathan Riley-Smith, The Crusades: A History, 2nd ed. (London: Continuum, 2005), 124.
} 
Darius von Güttner Sporzyński - 'Recent Issues in Polish Historiography of the Crusades.' Presented at the Fourth International Conference of the London Centre for the Study of the Crusades, the Military Religious Orders and the Latin East, St John's Gate, London, 8-11 September 2005.

Eastern Europe and the idea of crusade' held in Zielona Góra in $1999 .{ }^{32}$ For example, Mikołaj Gładysz analysed the involvement of Poles in the crusades in the Holy Land, Pomerania, Prussia and Sudovia between 1195 and 1291. He attempted to position Polish crusading within a European crusading effort, papal policy and Piast foreign policy. Gładysz proposed numerous hypotheses. Among the most notable are his proposals in regards to the multiple pilgrimages of a Polish noble, Jaksa of Miechów to the Holy Land in 1147 and 1162, and two crusading spells by Henry of Sandomierz in 1147 and 1154. Gładysz's study is a far ranging attempt to unearth the 'forgotten crusaders' and I have no doubt will provide stimulus to further studies of the manifestations of crusading ideology in Poland. ${ }^{33}$

Maria Starnawska presented the results of her detailed archival research into the crusading orders such as the Hospitallers, Templars, Knights of Christ, Knights of Calatrava and some smaller institutions. ${ }^{34}$ Starnawska analysed the inception of the orders' engagements in Poland, the endowments of commanderies and their location adjunct to the local crusading effort. She presented the previously unknown engagement of the orders in the community through the network of preceptories. Starnawska commented on the forms of their adaptation which resulted in support lent to local parishes, the maintenance of hospices and hospitals, the management of landed estates, and the inevitable involvement in local politics. Starnawska argued that all of the orders, despite their individual characteristics, were subject to similar adaptation pressures. The orders' Polish centres were located in a country far from the

\footnotetext{
${ }^{32}$ Wojciech Peltz, ed., Rycerstwo Europy środkowo-wschodniej wobec idei krucjat (Zielona Góra: Wydawnictwo Uniwersytetu Zielonogórskiego, 2002). Among recent publications there is a useful summary of the main issues of Polish participation in the crusades by Ossowska, "The Polish Contribution to the Expeditions to the Holy Land in the Crusades' era." Another article attempted to present and interpret the influence of the papal appeals for help for the Holy Land addressed to Poland. However the author's assertion that Pope Urban II in his appeal at Clermont also addressed Poland may be considered an overly hopeful interpretation. See A. Kowalska, Papieskie apele do Polski w sprawie pomocy dla Ziemi Świętej (XII-XIV w.), Acta Universitatis Lodziensis, Folia Historica, 67 (Łódź: Wydawnictwo Uniwersytetu Łódzkiego, 2000).

${ }^{33}$ Gładysz, "W sprawie udziału."; Gładysz, "Udział Polski."; Gładysz, "O zapomnianych polskich krzyżowcach."

34 Maria Starnawska, "Mnisi-rycerze-szlachta. Templariusze i joannici na pograniczu wielkopolskobrandenbursko-pomorskim," Zapiski Historyczne 99, no. 1 (1992); Maria Starnawska, "Rola polskich zakonów krzyżowych w ruchu pielgrzymkowym," in Pielgrzymki w kulturze średniowiecznej Europy: materiały XIII Seminarium Mediewistycznego, ed. Jacek Wiesiołowski, Sprawozdania PTPN, Wydział Nauki o Sztuce, 110 (Poznań: Poznańskie Towarzystwo Przyjaciół Nauk, 1993); Maria Starnawska, "Krucjata a Ziemia Święta w duchowości zakonów krzyżowych w Polsce średniowiecznej," Saeculum Christianum: pismo historyczno-społeczne 3, no. 1 (1996); Maria Starnawska, "Crusade Orders on Polish Lands During the Middle Ages: Adaptation in a Peripheral Enviroment," Quaestiones medii aevi novae 2 (1997); Maria Starnawska, Między Jerozolima a Eukowem: zakony krzyżowe na ziemiach polskich w średniowieczu (Warszawa: DiG, 1999).
} 
Darius von Güttner Sporzyński - 'Recent Issues in Polish Historiography of the Crusades.' Presented at the Fourth International Conference of the London Centre for the Study of the Crusades, the Military Religious Orders and the Latin East, St John's Gate, London, 8-11 September 2005.

main theatres of the crusading effort but absorbed the idea of crusade to such a degree that they directed their Christianising efforts towards their pagan neighbours.

\section{Conclusion}

At the inception of crusading, Poland was peripheral to the main crusading effort directed to the Near East, therefore the Levantine crusades do not feature greatly in Polish historiography. A strong feature of the historiography is however, the wars and expeditions against pagan Pomeranians, Prussians and Sudovians which displayed the characteristics of holy wars. By the middle of the thirteenth century the growing presence of the Teutonic Order in Prussia exposed the Poles to missionary crusades, and Polish research has been dominated by the consideration of the Polish struggle with the Teutonic Order which intensified in the fourteenth century.

Poland formed part of Latin Christendom after the tenth century, and its rulers and elites aspired to be respected members. Polish historiography reveals that crusading by the Poles generally followed patterns similar to those of the Western European crusading. It identified the crusades broadly with holy war and fighting in defence of the faith; its participants gave expression to their collective religious enthusiasm, to carry out the will of God and to win forgiveness for sins. The distinct feature of Polish crusading presented in the historiography is that the attractiveness of crusading was limited to the elites who were enthusiastic, if selective, supporters of the idea of crusade. They responded to, or made use of, crusade propaganda, campaigns and ideology. For Poles crusading was inherent in their acceptance of Christianity and they executed Christ's exhortation to spread his teachings to all the peoples of the world, in particular to their pagan neighbours. ${ }^{35}$

Medieval Poland was a country with close cultural and economic links with the rest of Europe and therefore presents an interesting illustration of a state and society developing through the process of integration into Christendom. Polish research offers new interpretations on the origins of European identity and hence demonstrates the general relevance of the study of medieval Europe to understanding today. Polish historiography of the crusades is relatively unknown to Western scholars, thus aspects

\footnotetext{
${ }^{35}$ Cf. Mark (16: 15-16) and Matthew (28: 18-19)
} 
Darius von Güttner Sporzyński - 'Recent Issues in Polish Historiography of the Crusades.'

Presented at the Fourth International Conference of the London Centre for the Study of the Crusades, the Military Religious Orders and the Latin East, St John's Gate, London, 8-11 September 2005.

of Polish culture, and the culture of crusading in particular, are absent from Western studies of the crusades. Wider access to the results of Polish research would not only unearth currently unexplored sources but also enrich the debate on the nature of crusading, and the motivation of participants. 


\section{Printed Primary Sources and Other Works Cited}

Annales Magdeburgenses. Edited by George H. Pertz. Vol. 16, Monumenta Germaniae Historica Scriptores. Hannoverae 1861.

Belch, Stanislaus F. Paulus Vladimiri and His Doctrine Concerning International Law and Politics. 2 vols. The Hague: Mouton, 1965.

Bernhardi, Wilhelm. Konrad III. 2 vols, Jahrbücher Deutschen Geschichte. Leipzig: Duncker and Humblot, 1883.

Bersohn, Mathias. Kilka słów o polskich podróżnikach do Ziemi Świętej i ich dziełach [A Few Words About Polish Travellers to the Holy Land and Their Deeds], Biblioteka Warszawska, 4. Warsaw, 1868.

Biskup, Marian, and Gerard Labuda. Dzieje zakonu krzyżackiego w Prusach [History of the Teutonic Order in Prussia]. Gdańsk, 1988.

Bogusławski, Wilhelm Józef. Dzieje Stowiańszczyzny pótnocno-zachodniej do połowy XIII wieku [History of the North Western Slavs till the Middle of the Thirteenth Century]. 3 vols. Vol. 3. Poznań, 1892.

Bystroń, Jan Stanisław. Polacy w Ziemi Świętej, Syrji i Egipcie 1747-1914 [Poles in the Holy Land, Syria and Egypt]. Kraków, 1930.

Długosz, Jan. Joannis Dlugossii Annales seu Cronicae incliti Regni Poloniae. Lib. 5 6. Edited by Krystyna Pieradzka, Zofia Kozłowska-Budkowa and Danuta Turkowska. Varsaviae: Państwowe Wydawnictwo Naukowe, 1973.

Dowiat, Jerzy. "Ekspansja Pomorza Zachodniego na ziemie wielecko-obodrzyckie w drugiej połowie XII wieku." [Expansion of Western Pomerania into the Lands of the Wends in the Second Half of the Twelfth Century] Przeglad Historyczny 50, no. 4 (1959).

Dworsatschek, Mariusz. Władysław II Wygnaniec [Władysław the Exile]. Wrocław: Towarzystwo Przyjaciół Ossolineum, 1998.

Erdmann, Carl. Die Entstehung des Kreuzzugsgedankens. Stuttgart, 1935.

Gieysztor, Aleksander. Ze studiów nad genezq wypraw krzyżowych: encyklika Sergiusza IV (1009-1012) [The Genesis of the Crusades: the Encyclical of Sergius IV (1009-1012)]. Warszawa: Towarzystwo Naukowe Warszawskie, 1948.

Gładysz, Mikołaj. "W sprawie udziału polskiego księcia w II krucjacie jerozolimskiej (1147-1149)." [The Issue of Participation by a Polish Prince in the Second Crusade 1147-1149] In Krzyżowcy, kronikarze, dyplomaci, edited by Błażej Śliwiński, 33-52. Gdańsk-Koszalin, 1997.

. "Udział Polski w V krucjacie lewantyńskiej (1217-1221)." [Polish Participation in the Fifth Levantine Crusade] In Szlachta, starostowie, zaciężni, edited by Błażej Śliwiński, 63-82. Koszalin: Wydawnictwo Miscellanea, 1998.

. "O zapomnianych polskich krzyżowcach: kilka uwag na marginesie wypraw jerozolimskich księcia Henryka Sandomierskiego i Jaksy z Miechowa." [Forgoten Polish Crusaders: Some Remarks on the Sidelines of Pilgrimages to Jersusalem by Henry Duke of Sandomierz and Jaksa of Miechów] In Ksiażęta, urzędnicy, złoczyńcy, edited by Błażej Śliwiński, 45-64. Gdańsk: Officina Ferberiana, 1999.

—. Zapomniani krzyżowcy [The Forgoten Crusaders]. Warszawa: DiG, 2002.

Grabski, Andrzej F. "Polska wobec idei wypraw krzyżowych na przełomie XI i XII wieku: duch krzyżowy Anonima Galla." [Poland and the Idea of Crusade at 
the Turn of Eleventh and Twelfth Century: the Crusading Spirit of Gallus Anonymous] Zapiski Historyczne 26 (1961): 37-63.

Grodecki, Roman. "Polska wobec idei wypraw krzyżowych." [Poland and the Idea of the Crusade] Przeglad Wspótczesny 2, no. 18 (1923): 103-116.

. "Dzieje Polski do roku 1194." [A History of Poland to 1194] In Dzieje Polski Średniowiecznej [A History of Medieval Poland], edited by Roman Grodecki, Stanisław Zachorowski and Jan Dąbrowski, 25-210. Kraków: Wydawnictwo Platan, 1995.

Gumowski, Marian. "Sprawa braniborska XII wieku." [The Affair of Branibor in the Twelfth Century] Slavia Occidentalis 7 (1928).

Iwańczak, Wojciech. "Udział Czechów w krucjatach do Ziemi Świętej." [The participation of Czechs in crusades to the Holy Land] In Peregrinationes: Pielgrzymki w kulturze dawnej Europy, edited by Halina Manikowska and Hanna Zaremska, 118-125. Warszawa: Instytut Historii PAN, 1995.

Jasiński, Tomasz. Najstarsze kroniki i roczniki krzyżackie dotyczqce Prus [The Oldest Chronicles and Annals of the Teutonic Order in Prussia]. Vol. 52, Prace Komisji Historycznej. Poznań: Poznańskie Towarzystwo Przyjaciół Nauk, 1956.

Kinnamos, John. Deeds of John and Manuel Comnenus. Translated by Charles M. Brand. New York: Columbia University Press, 1976.

Knoll, Paul W., and Frank Schaer, eds. Gesta Principium Polonorum: the Deeds of the Princes of the Poles. Edited by Frank Schaer, Central European Medieval Texts, vol 3. Budapest-New York: Central European University Press, 2003.

Korwin-Pawłowski, Stanisław A. Stosunki Polski z Ziemiq Święta [Relations between Poland and the Holy Land]. Warszawa: Instytut Wydawniczy PAX, 1958.

Kowalska, A. Papieskie apele do Polski w sprawie pomocy dla Ziemi Świętej (XII$X I V$ w.) [Papal Appeals to Poland for Assistance to the Holy Land], Acta Universitatis Lodziensis, Folia Historica, 67. Łódź: Wydawnictwo Uniwersytetu Łódzkiego, 2000.

Labuda, Gerard. "Rola Wielkopolski w utrwaleniu rozdrobnienia feudalnego w Polsce." [The Role of Great Poland in Preserving the Feudal Fragmentation of Poland] In Dzieje Wielkopolski, edited by Jerzy Topolski. Poznań, 1969. . "O źródłach "Kroniki Pruskiej” Piotra z Dusburga." [Sources of the "Prussian Chronicle" by Peter of Dusburg] Komunikaty Mazursko-Warmińskie, no. 2-3 (1971): 217-243.

. "Wezwanie wschodnioniemieckich feudałów do walki ze Słowianami roku 1108." [The Appeal by the German Eastern Feudal Lords to War with the Slavs in 1108] In Fragmenty dziejów Słowiańszczyznv Zachodniej, edited by Gerard Labuda, 233-269. Poznań: Poznańskie Towarzystwo Przyjaciół Nauk, 1975.

Mendys, Michał. "Udział Władysława II w krucjacie 1147." [Participation by Władysław II in the Second Crusade] Rocznik Zakładu Naukowego im. Ossolińskich 1 (1927): 399-434.

Mitkowski, Józef. Pomorze Zachodnie w stosunku do Polski [Western Pomerania and Its Relations with Poland]. Edited by Prace Instytutu Zachodniego. Poznań: Wydawnictwo Instytutu Zachodniego, 1946.

Myśliński, Kazimierz. Bogusław I ksiaże Pomorza Zachodniego [Bogusław I Duke of Western Pomerania], Wydawnictwa Instytutu Battyckiego. Prace BadawczoNaukowe. Seria: Rozprawy. Bydgoszcz: Instytut Bałtycki, 1948. 
Darius von Güttner Sporzyński - 'Recent Issues in Polish Historiography of the Crusades.' Presented at the Fourth International Conference of the London Centre for the Study of the Crusades, the Military Religious Orders and the Latin East, St John's Gate, London, 8-11 September 2005.

"Polska a Pomorze Zachodnie po śmierci Krzywoustego." [Poland and Western Pomerania After the Detah of Boleslaw the Wrymouth] Roczniki Historyczne 17 (1948).

. "Sprawa udziału Polski w niemieckiej wyprawie na Słowian Połabskich." [The Issue of Polish participation in the German Expedition against the Polabian Slavs] In Ars Historica. Prace z dziejów powszechnych i Polski. Poznań: Uniwersytet im. Adama Mickiewicza, 1976.

. "Księstwo Saskie a Polska w XII wieku." [Saxony and Poland in the Twelfth Century] In Niemcy - Polska w Średniowieczu. Materiaty z konferencji naukowej zorganizowanej przez Instytut Historii UAM w dniach 14-16 XI 1983 roku, edited by Jerzy Strzelczyk, 171-186. Poznań, 1986.

- Polska wobec Stowian połabskich do końca wieku XII [Poland and the Polabian Slavs till the end of the Twelfth Century]. Lublin: Wydawnictwo UMCS, 1993.

Ossowska, Jadwiga. "The Polish Contribution to the Expeditions to the Holy Land in the Crusades' era." Folia Orientalia 26 (1989): 165-182.

Ostrogorski, Georgije. Dzieje Bizancjum [A History of Byzantium]. Translated by Halina Evert-Kappesowa. Warszawa: Państwowe Wydawnictwo Naukowe, 1967.

Peltz, Wojciech, ed. Rycerstwo Europy środkowo-wschodniej wobec idei krucjat [The Knighthood of Central and Eastern Europe and the Idea of Crusade]. Zielona Góra: Wydawnictwo Uniwersytetu Zielonogórskiego, 2002.

Plezia, Marian, ed. Magistri Vincentii dicti Kadtubek Chronica Polonorum. Edited by Marian Plezia, Monumenta Poloniae Historica n.s. Kraków: Polska Akademia Umiejętności, 1994.

Pollakówna, Marzena. Kronika Piotra z Dusburga [The Chronicle of Peter of Dusburg]. Wrocław, 1968.

Powierski, Jan. Stosunki polsko-pruskie do 1230 roku ze szczególnym uwzględnieniem roli Pomorza Gdańskiego [Relations Between Poland and Prussia before 1230 With a Particular Discussion of the Role of Gdansk-Pomerania], Roczniki Towarzystwa Naukowego w Toruniu. Poznań: Państwowe Wydawnictwo Naukowe, 1968.

. "Polska a Prusy do połowy XIII wieku." [Poland and Prussia until the end of the Thirteenth Century] In Dzieje Warmi i Mazur w zarysie. Warszawa, 1981. - Prusowie, Mazowsze i sprowadzenie Krzyżaków do Polski [Prussia, Mazovia and the Invitation of Teutonic Knights to Poland]. Malbork: Muzeum Zamkowe, 1996.

_. Prussica : artykuly wybrane z lat 1965-1995 [Prussica. Selected Articles published between 1965-1995]. Malbork: Muzeum Zamkowe, 2004.

Riley-Smith, Jonathan. "Family Traditions and Participation in the Second Crusade." In The Second Crusade and the Cistercians, edited by Michael Gervers, 101108. New York: St. Martin's Press, 1992.

. The Crusades: A History. 2nd ed. London: Continuum, 2005.

Rousset, Paul. Les origines et les caractères de la première croisade. Genáeve: Imprimerie A. Kundig, 1945. Reprint, 1978.

Silnicki, Tadeusz. "Początki chrześcijaństwa i organizacji kościelnej na Pomorzu." [The Begining of Christianity and the Church Hierarchy in Pomerania] In $Z$ dziejów kościola w Polsce: studia i szkice historyczne, edited by Tadeusz Silnicki. Warszawa: Wydawnictwo Pax, 1960. 
Darius von Güttner Sporzyński - 'Recent Issues in Polish Historiography of the Crusades.'

Presented at the Fourth International Conference of the London Centre for the Study of the Crusades, the Military Religious Orders and the Latin East, St John's Gate, London, 8-11 September 2005.

Ślaski, Kazimierz. "Pomorze Zachodnie w dobie rozwijającego się feudalizmu (11241464)." [Western Pomerania During the Feudal Times (1124-1464)] In Historia Pomorza, edited by Gerard Labuda, Kazimierz Ślaski and Benedykt Zientara. Poznań: Wydawnictwo Poznańskie, 1969.

Smolka, Stanisław. Mieszko Stary i jego wiek [Mieszko the Old and his times]. Edited by Aleksander Gieysztor. Warszawa: Gebethner i Wolff, 1881. Reprint, Warszawa: Państwowe Wydawnictwo Naukowe, 1959.

Spors, Józef. Studia nad wczesnośredniowiecznymi dziejami Pomorza Zachodniego: XII - pierwsza połowa XIII wieku [Studies of the Early Medieval History of Western Pomerania (between the Twelfth Century and the First Half of the Thirteenth Century)]. Słupsk: Pobrzeże, 1988.

Starnawska, Maria. "Mnisi-rycerze-szlachta. Templariusze i joannici na pograniczu wielkopolsko-brandenbursko-pomorskim." [Monks-Knights-Nobles: the Knights Templar and Hospitallers on the Borderlands of Great Poland, Brandenburg and Pomerania] Zapiski Historyczne 99, no. 1 (1992): 3-31. . "Rola polskich zakonów krzyżowych w ruchu pielgrzymkowym." [The Role of the Crusading Orders in the Pilgrimage Movement in Poland] In Pielgrzymki w kulturze średniowiecznej Europy: materiały XIII Seminarium Mediewistycznego, edited by Jacek Wiesiołowski, 109-115. Poznań: Poznańskie Towarzystwo Przyjaciół Nauk, 1993.

. "Krucjata a Ziemia Święta w duchowości zakonów krzyżowych w Polsce średniowiecznej." [Crusade and the Holy Land in the Spirituality of the Crusading Orders in Medieval Poland] Saeculum Christianum: pismo historyczno-spoteczne 3, no. 1 (1996): 167-179.

. "Crusade Orders on Polish Lands During the Middle Ages: Adaptation in a Peripheral Enviroment." Quaestiones medii aevi novae 2 (1997): 121-142. - Między Jerozolima a Łukowem: zakony krzyżowe na ziemiach polskich w średniowieczu [The Crusading Orders in Poland in the Middle Ages]. Warszawa: DiG, 1999.

Trupinda, Janusz. Ideologia krucjatowa w Kronice Piotra z Durburga [Crusading Ideology in the Chronicle of Peter of Dusburg]. Gdańsk: Officina Ferberiana, 1999.

Villey, Michel. La croisade: Essai sur la formation d'une théorie juridique. Paris, 1942. Reprint, 1980.

Wenta, Jarosław. "Kronika Piotra z Duisburga a dzieje Zakonu Krzyżackiego zawarte w Kronice oliwskiej." [Chronicle of Peter of Dusburg and the History of the Teutonic Order in the Chronicle of Oliwa] Studia Źródłoznawcze 25 (1970): 121-131.

. Kierunki rozwoju rocznikarstwa w państwie Zakonu Niemieckiego w XIIIXVI wieku [The Direction of Development of the Annals in the State of Teutonic Order in the Thirteeth and Fourteenth Century], Roczniki Towarzystwa Naukowego w Toruniu. Torun Towarzystwo Naukowe w Toruniu, 1990.

- Kronika Piotra z Dusburga: szkic źródłoznawczy [The Chronicle of Peter of Dusburg: The Sources]. Torun: Wydawnictwo Uniwersytetu Mikołaja Kopernika, 2003. , ed. Kronika ziemi pruskiej Piotra z Dusburga [The Chronicle of Prussia by Peter of Dusburg]. Toruń: Wydawnictwo Uniwersytetu Mikołaja Kopernika, 2004. 
Darius von Güttner Sporzyński - 'Recent Issues in Polish Historiography of the Crusades.'

Presented at the Fourth International Conference of the London Centre for the Study of the Crusades, the Military Religious Orders and the Latin East, St John's Gate, London, 8-11 September 2005.

Włodarski, Bronisław. "O udziale Polski w wyprawie krzyżowej Andrzeja II w 1217 roku." [The Participation of Poles in the Crusade of Andrzej II in 1217] Kwartalnik Historyczny 38, no. 1-2 (1924): 29-36.

Zakrzewski, Stanisław. "Wschód i Zachód w historii Polski." [The West and the East in the History of Poland] In Zagadnienia historyczne, edited by Stanisław Zakrzewski. Lwów: Księgarnia H. Altenberga, 1908.

. "Okres do schyłku XII wieku." [The History of Poland until the Twelfth Century] In Encyklopedia polska vol. 5, p. 1, Historya polityczna Polski, p. 1: Wieki średnie, edited by Stanisław Zakrzewski. Kraków: Polska Akademia Umiejętności, 1920.

Zientara, Benedykt. "Stosunki polityczne Pomorza Zachodniego z Polską w drugiej połowie XII wieku." [The Political Relations of Western Pomerania and Poland in the Second Half of the Twelfth Century] Przeglad Historyczny 61, no. 4 (1970).

. "Afterword to "Dzieje wypraw krzyżowych"." In Polish edition of A History of Crusades by Steven Runciman, 457-460. Warszawa: Państwowy Instytut Wydawniczy, 1987. 


\section{University Library}

\section{- M M I E E R VA A gateway to Melbourne's research publications}

Minerva Access is the Institutional Repository of The University of Melbourne

Author/s:

VON GUETTNER, D

Title:

Recent Issues in Polish Historiography of the Crusades

Date:

2008

Citation:

VON GUETTNER, D. (2008). Recent Issues in Polish Historiography of the Crusades. The Military Orders, 4, pp.13-21. Ashgate.

Publication Status:

Inpress

Persistent Link:

http://hdl.handle.net/11343/34224 